\title{
New systematic results based on chaetal hard structures in Mesochaetopterus (Polychaeta)
}

\author{
MICHEL BHAUD ${ }^{1}$, BYOUNG-SEOUL $\mathrm{KOH}^{2}$ and DANIEL MARTIN ${ }^{3}$ \\ ${ }^{1}$ Observatoire Océanologique de Banyuls, Université P. et M. Curie - CNRS, BP 44, 66651 Banyuls-sur-mer, Cedex, \\ France. E-mail : mbhaud@obs-banyuls.fr \\ ${ }^{2}$ Marine Living Resources Research Division, Korea Ocean Research \& Development Institute, Ansan P.O. Box 29, \\ Seoul 425-600, Korea. \\ ${ }^{3}$ Centre d'Estudis Avançats de Blanes (CSIC), Carrer d'accés a la Cala Sant Francesc 14, 17300 Blanes (Girona), \\ Catalunya, Spain.
}

SUMMARY: Two kinds of chaetal hard structures have been analysed within the genus Mesochaetopterus (Chaetopteridae, Polychaeta): the specialised chaetae of the fourth segment of the anterior part of the body (i.e. the A4 segment) and the uncinal plates present on neuropodia of mid and posterior parts (i.e. B- and C-regions, respectively). The examination of a large number of specimens leads to identification of finer geographic differences based on the morphological variations of these chaetal hard structures than on criteria linked to the soft body structures. These differences may be considered as specieslevel markers with a high degree of certainty. As a consequence, the reintroduction of $M$. sagittarius (Claparède, 1870) is proposed for specimens from the Atlantic and the Mediterranean Sea, while M. minutus (Potts, 1914) is retained for some specimens from the Pacific Ocean. The specimens from the Persian (= Arabian) Gulf seem to be different from those of the Indian Ocean, likely a new species of the genus. Geographic differentiation is also observed over shorter distances and two morphologies of A4 chaetae are identified on specimens from the Solomon's archipelago, suggesting also the presence of new species. However, other taxonomically valid characters should be explored, in addition to the chaetal hard structures described herein, to formally describe these species. This research adds to the growing literature that suggests truly cosmopolitan species, specifically within the genus Meesochaetopterus and possibly within the Chaetopteridae as a whole, are increasingly difficult to find.

Keywords: chaetal hard structures, chaetopterid, Annelida, systematics, geographical distribution.

RESUMEN: Nuevos Resultados Sistematicos basados en las quetas de Mesochaetopterus (Polychaeta). - Dos clases distintas de estructuras duras se han analizado en el género Mesochaetopterus (Annelida, Polychaeta): las sedas especializadas del cuarto segmento de la región anterior del cuerpo (región A4) y las placas uncinígeras presentes en los neuropodios de las regiones media y posterior (regiones B y C, respectivamente). El estudio de dichas estructuras en un elevado número de ejemplares ha permitido identificar diferencias relacionadas con la distribución geográfica con una mayor precisión que en base a criterios relacionados con las partes blandas de cuerpo. Ciertamente, dichas diferencias pueden considerarse marcadores específicos. Como consecuencia, se propone la reintroducción de M. sagittarius (Claparède, 1870) para las poblaciones atlanto-mediterráneas, mientras que se retiene M. minutus (Potts, 1914) para determinadas poblaciones del Pacífico. Los ejemplares del Golfo Pérsico parecen ser distintos de los del Índico, pudiendo ser probablemente una especie nueva. Diferencias ligadas a la distribución geográfica se han identificado también a una escala espacial menor, concretamente dos morfologías diferentes de la seda modificada A4 en ejemplares de dos poblaciones del Archipiélago de Salomón, lo cual sugiere también la presencia de especies nuevas en la zona. Sin embargo, se considera necesario el estudio de otros caracteres taxonómicamente válidos, además de la estructuras duras de las sedas especializadas y las placas uncinígreras, previamente a proceder a la descripción formal de dichas especies. En resumen, cabe decir que, probablemente en el conjunto de la familia y, ciertamente, en el género Mesochaetopterus la existencia de especies cosmopolitas es cada vez más difícil de ser mantenida.

Palabras clave: estructuras duras de las quetas, Chaetopteridae, Annelida, sistemática, distribución geográfica. 


\section{INTRODUCTION}

Two kinds of hard structures are present in Chaetopteridae: specialized chaetae or stout spines of the fourth segment of the anterior part of the body (i.e. the A4 segment) and uncinal plates present on neuropodia of mid and posterior parts of the body (i.e. B- and C-regions, respectively). Stout spines on A4 are used for cutting the tube or for tube divisions (Barnes, 1965). There may be only a single pair of cutting spines, one on each parapodium (such as on some Phyllochaetopterus and on all Spiochaetopterus), or as many as 10 on each notopodium (such as in Mesochaetopterus and Chaetopterus) (Fig. 1 in Bhaud, 2003). The structure of these spines has been recommended as a useful taxonomic feature (Kudenov, 1975). However, chaetal hard structures were ignored in the identification of polychaete species for a long time. They were used only at the family or order levels (e.g. Terebellomorpha in Holthe, 1986).

Chaetal hard structures have seldom been used solely to differentiate species. Nevertheless, a few examples can be found. Among Pectinariidae, the morphology of uncinal plates was used to distinguish between Pectinaria californiensis (Hartman, 1941) and P. regalis (Long, 1973), while Lana \& Bremec (1994) used paleae in their review of the south American region. Knight-Jones (1994) also used thoracic uncinal plates for the Sabellidae; Vogt \& Kudenov (1994) used bifurcate notochaetae in Euphrosinidae and Watson-Russell (1998) used mid-body palae among Chrysopetalidae, to build a key for the genus Arichlidon.

Recent studies on the morphology of Chaetopteridae (Kudenov, 1975; Bhaud, 1998; Nishi et al., 1999; Nishi and Bhaud, 2000) based on chaetal hard structures from the segment A4 specialised chaetae and uncinal plates of B- and C-regions, pointed to the necessity of a detailed study of the family. Accordingly, the aim of the present paper is to define the ranges of variability of the chaetal hard structures within the small-bodied species of the genus Mesochaetopterus, specifically focusing on the potential existence of cosmopolitan species.

\section{MATERIAL AND METHODS}

Uncinal plates were observed through a Diaplan Leitz light microscope and photographs were taken with a Leica-Wild MPS 32. Observations of A4 chaetae were made using a Hitachi S4500 Scanning Electron Microscope (SEM) at the Centre of Electron Microscopy of the University of Perpignan (France) by the first author. To allow valid comparisons, all uncinal plates were taken from the first or second segment of the middle region. For SEM observations formalin-preserved body parts were twice rinsed with distilled water (one hour each bath), in order to dissolve the numerous mineral concretions and to eliminate formaldehyde crystals. They were then run through a series of ethanol concentrations, and stored in $90 \%$ ethanol until required. Immediately prior to viewing them, they were transferred to $100 \%$ alcohol, air-dried, mounted on a grid with double-sided sticky tape, attached to a stub and coated with gold palladium.

The descriptions of uncinal plates were based on the study of Terebellomorpha by Holthe (1986), who described "the typical terebellomorph avicular uncinus" and pointed out that "the sheathed manubriavicular uncinus can be viewed as the original form from which most of the uncini in several sedentary families can be derived". However, the uncini in Chaetopteridae are monopectinate and the homology between these two types of plate is not clear. Both the rostrum and subrostral process cannot be clearly identified in chaetopterids and the anterior and posterior processes seem to differ in nature. The filament and the main body of the plate are linked through a divergence of the fibres composing the filament, which constitute a hood covering the anterior region (namely the capitium) that may be joined to the anterior process.

A detailed description of A4 chaetae of Spiochaetopterus was first published by Bhaud (1998) and a schematic illustration based on SEM observations was given for all genera of the family (Bhaud, 2003, Fig.1; cf. also Kudenov, 1975). In Mesochaetopterus and Chaetopterus, the A4 specialised chaetae are numerous (between 5 and 10) and vary in shape from the anterior-most to the posterior-most, with a progressive transition from head to shaft. These two parts are not as well separated as in Spiochaetopterus. The general shape is flattened, with a lateral compression defining a plane of symmetry where the side of the chaetal head having many cusps is considered as the ventral face. The dorso-ventral axis is thus perpendicular to the direction of flattening. The head terminates in a dorsal point. The ventral transition from the shaft to the end 
of the chaeta has a variable profile, being either convex over the whole height of the head or having a more or less pronounced horizontal plateau halfway up the head. Along the A4 segment, the chaetae are aligned in such a way that their ventral sides face the central axis of the dorsum of the body.

Specimens belonging a priori to Mesochaetopterus minuta Potts, 1914 from eight geographical sources, referred to as "S", have been analysed:

S1. - Paratypes. Cape Verde Islands; Cambridge University Museum, C. Crossland coll., July and August 1904.

S6. - Persian Gulf from Umm Al Maradim, off Kuwait (northern Persian Gulf), gregarious fragile sand tubes, British Museum (see Mohammad, 1980); Iranian coast, between Asaluyeh and Nakhl e Taqi at the north of the Nay Band Bay, $250 \mathrm{~km}$ south of Bander Bousher (Central Persian Gulf), E. Dutrieux coll. 1998 and 2002 (D. Martin personal collection).

S3. - Durban, from Isipingo beach; Prof. T. A. Stephenson coll. 27/6/1935.

S5. - East coast of India, from Krusadai Island, Gulf of Manaar; Madras, Gravely coll.

S2. - Solomon Islands A, from Komimbo Bay, Royal Society Expedition to the Solomon Islands; coarse coral sand; Gibbs coll. 20/2/1965.

S8. - Solomon Islands B, from Yandina wharf, $5 \mathrm{~m}$ depth, on and within sponge Halichondria; Royal Society Expedition to the Solomon Islands; Gibbs coll. 5/11/1965.

S9. - Solomon Islands C, from Fintry Point, silty sand and shell gravel; Royal Society Expedition to the Solomon Islands; Gibbs coll. 8/10/1965.

S7. - Galapagos Islands, Mesochaetopterus minutus?; Dr. C. Crossland coll. 1933.

\section{RESULTS}

\section{Uncinal plates}

S1 specimens have uncinal plates with the posterior dorsal face inclined with respect to the direction of the toothed crest, distinctly separated teeth, distinctive heel, wavy ventral insertion zone and first anterior tooth resting on a rounded anterior process (Fig. 1, row 1).

S6 specimens have a convex toothed crest, distinctly separated teeth and anterior process not cov- ered by the first tooth. Careful observations revealed that some plates apparently having a slightly convex ventral line at the insertion zone had been excessively squashed when mounted - the natural shape being with a markedly concave ventral line (Fig. 1, row 2 ).

$\mathrm{S} 3$ specimens closely resembled $\mathrm{S} 1$ specimens in having a posterior dorsal line inclined with respect to the direction of the toothed crest and distinctly separated teeth (Fig.1 row 3). However, the S1 specimens have a wavy ventral insertion zone, whereas it is slightly convex in the S3 specimens, and the first tooth has not the same importance relatively to the anterior process, and finally the posterior borders are also different.

The oval shape and antero-posterior symmetry of uncinal plates from S5 specimens are very characteristic (Fig.1 row 4).

S2, S8 and S9 specimens, all of them from the Solomon Islands, are not homogeneous (Fig. 1, rows 5, 6 and 7). S2 and S9 differ from S8 in that their uncinal plates have close-set teeth touching each other, a heel almost straight and perpendicular to the sole, a first tooth not overlapping the anterior process, which itself has an upper edge free over a long distance. Conversely, on S8 uncinal plates have widely separated teeth, a heel oblique relative to the sole and first teeth covering a large part of the anterior process. They also differ in size.

S7 specimens have markedly specific uncinal plates, having an inclined rectilinear posterior profile, rectilinear ventral insertion zone and only a few teeth (Fig. 1, row 8).

Main characteristics of uncinal plates for each of these eight populations of Mesochaetopterus are shown in Table 1.

A4 chaetae Besides the short descriptions and the clear variation in shape inside each bundle, the collections studied allow identification of several features of the A4 chaetae that may be useful elements for further differentiation at species level. Among them, the head, flattened or more or less cylindrical, either with oblique profile or not, the size of the cusps, their shape, as large spines or short 'pavingstones', and the presence of the 'hull', may be the most relevant.

S1 specimens constituted the basis of the erection of $S$. minuta as a new species. Therefore, their morphology is particularly relevant. The A4 chaetae have ventral faces covered by large cusps, which are limited to 8-10 at the widest point of the ventral 

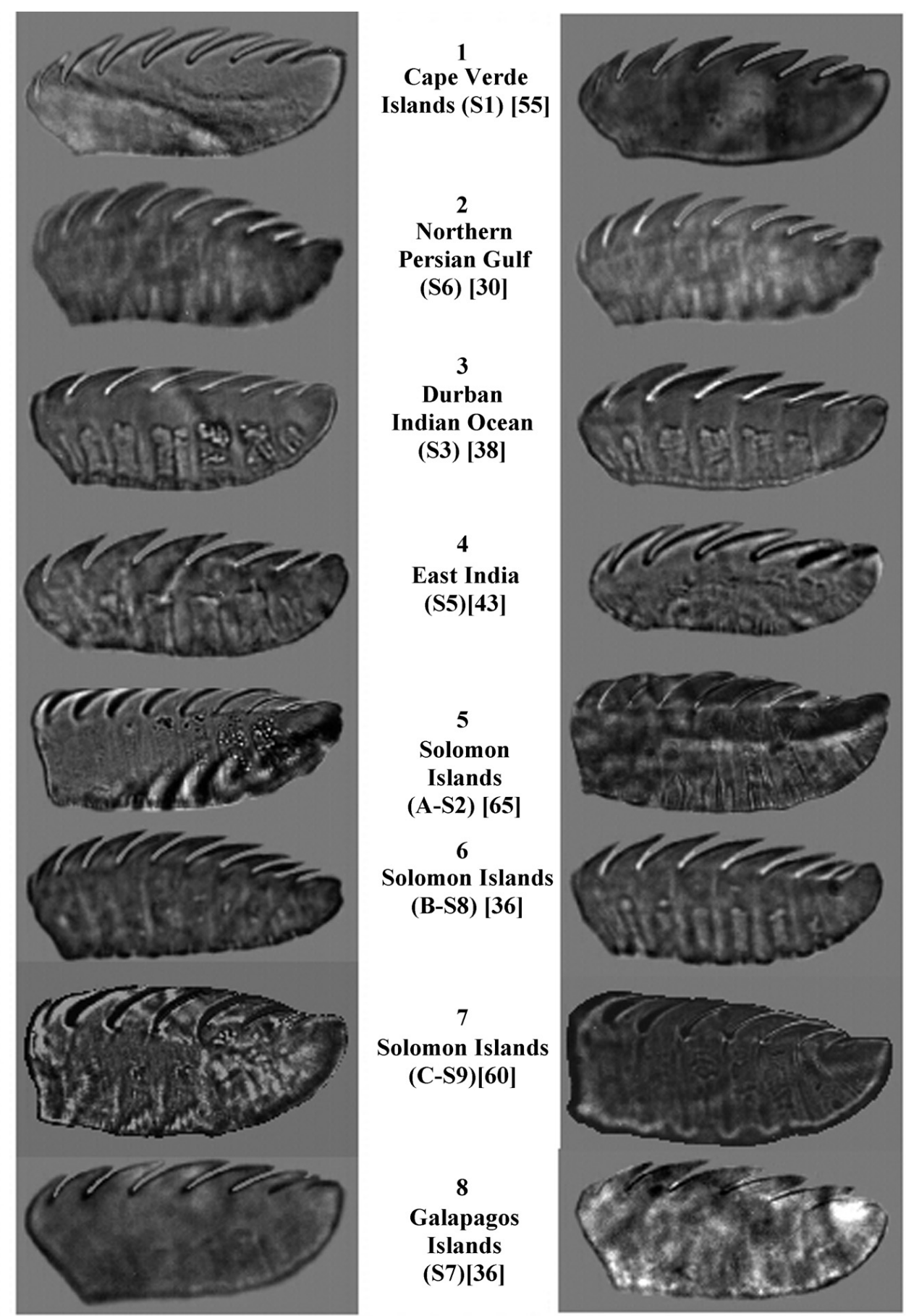

FIG. 1. - Examples of different uncinal plate morphologies in Mesochaetopterus, showing two images to cover a part of the whole range of variability at each geographical location. In brackets: code referring to the origin of the record. In square brackets: size $(\mu \mathrm{m})$.

face; a hull-shape is visible on certain chaetae but it is never axial; the teeth, which are shaped rather like paving-stones, are absent at the base of the stem (Fig. 2A).

S6 specimens are characterised by the singular hull-shaped protuberance, which is very fine and presents two faces to the ventral side of the A4 chaetae (Fig. 2B). This protuberance is developed on a very long and oblique part of the head. The specimens from the northern and central Persian Gulf show the same morphology.

S3 specimens have flattened A4 chaetae, with a ventral face covered by large cusps, which are present at the base of the stem (Fig. 2C).

S2 and S9 specimens have A4 chaetae with a more or less inclined plateau before the summit, a 
TABLE 1. - Comparison of different characteristic of uncinal plates in eight populations of Mesochaetopterus distributed in the Atlantic, Indian and Pacific Oceans.

\begin{tabular}{|c|c|c|c|c|c|c|c|}
\hline $\begin{array}{l}\text { Label and } \\
\text { origin }\end{array}$ & $\begin{array}{c}\text { Shape of } \\
\text { ventral } \\
\text { insertion zone }\end{array}$ & $\begin{array}{l}\text { Posterior face } \\
\text { (with respect } \\
\text { to sole) }\end{array}$ & $\begin{array}{l}\text { Number of } \\
\text { teeth }\end{array}$ & $\begin{array}{l}\text { Teeth } \\
\text { separation }\end{array}$ & $\begin{array}{c}1 \text { st tooth } \\
\text { covering }>50 \% \\
\text { anterior process }\end{array}$ & $\begin{array}{c}\text { Shape of } \\
\text { anterior process }\end{array}$ & Size $(\mu \mathrm{m})$ \\
\hline $\begin{array}{l}\text { S1 } \\
\text { Atlantic } \\
\text { Cape Verde Is }\end{array}$ & $\begin{array}{l}\text { slightly } \\
\text { convex and } \\
\text { wavy }\end{array}$ & $\begin{array}{l}\text { oblique, } \\
\text { with notch }\end{array}$ & 8 & $\begin{array}{l}\text { distinctly } \\
\text { separated }\end{array}$ & yes & $\begin{array}{l}\text { rounded } \\
\text { not flat }\end{array}$ & 55 \\
\hline $\begin{array}{l}\text { S6 } \\
\text { Persian Gulf }\end{array}$ & $\begin{array}{l}\text { clearly } \\
\text { convex }\end{array}$ & $\begin{array}{l}\text { inclined, } \\
\text { rectilinear }\end{array}$ & 9 & $\begin{array}{l}\text { moderately } \\
\text { separated }\end{array}$ & no & $\begin{array}{c}\text { flat and } \\
\text { horizontal }\end{array}$ & 30 \\
\hline $\begin{array}{l}\text { S3 } \\
\text { Southern Indian } \\
\text { Ocean, Durban }\end{array}$ & $\begin{array}{l}\text { slightly } \\
\text { convex }\end{array}$ & $\begin{array}{l}\text { inclined, } \\
\text { with knob }\end{array}$ & 7 & $\begin{array}{l}\text { distinctly } \\
\text { separated }\end{array}$ & no & $\begin{array}{l}\text { rounded } \\
\text { not flat }\end{array}$ & 38 \\
\hline $\begin{array}{l}\text { S5 } \\
\text { Eastern Indian } \\
\text { Ocean, Madras }\end{array}$ & $\begin{array}{l}\text { slightly } \\
\text { convex }\end{array}$ & rounded & $6-7$ & $\begin{array}{l}\text { distinctly } \\
\text { separated }\end{array}$ & no & $\begin{array}{l}\text { rounded } \\
\text { not flat }\end{array}$ & 43 \\
\hline $\begin{array}{l}\text { S2 } \\
\text { Western Pacific } \\
\text { Solomon Is }\end{array}$ & $\begin{array}{l}\text { rectilinear } \\
\text { then convex }\end{array}$ & $\begin{array}{l}\text { perpendicular to } \\
\text { the direction of } \\
\text { sole and } \\
\text { toothed crest }\end{array}$ & 8 & $\begin{array}{l}\text { moderately } \\
\text { separated }\end{array}$ & no & $\begin{array}{l}\text { flat, oblique } \\
\text { and long }\end{array}$ & 65 \\
\hline $\begin{array}{l}\text { S8 } \\
\text { Western Pacific } \\
\text { Solomon Is }\end{array}$ & rectilinear & $\begin{array}{l}\text { inclined, } \\
\text { with knob }\end{array}$ & $8-10$ & $\begin{array}{l}\text { distinctly } \\
\text { separated }\end{array}$ & no & $\begin{array}{l}\text { flat, horizontal } \\
\text { and long }\end{array}$ & 36 \\
\hline $\begin{array}{l}\text { S9 } \\
\text { Western Pacific } \\
\text { Solomon Is }\end{array}$ & $\begin{array}{l}\text { rectilinear } \\
\text { then convex }\end{array}$ & $\begin{array}{l}\text { perpendicular to } \\
\text { the direction of } \\
\text { sole and of } \\
\text { toothed crest }\end{array}$ & 7 & $\begin{array}{l}\text { moderately } \\
\text { separated }\end{array}$ & yes & $\begin{array}{l}\text { flat, horizontal } \\
\text { and long }\end{array}$ & 60 \\
\hline $\begin{array}{l}\text { S7 } \\
\text { Eastern Pacific } \\
\text { Galapagos Is }\end{array}$ & $\begin{array}{l}\text { slightly } \\
\text { convex }\end{array}$ & $\begin{array}{l}\text { inclined, } \\
\text { rectilinear }\end{array}$ & 7 & $\begin{array}{l}\text { moderately } \\
\text { separated }\end{array}$ & no & $\begin{array}{l}\text { rounded, } \\
\text { not flat }\end{array}$ & 36 \\
\hline
\end{tabular}

notable thickness and cusps present only on the plateau (Figs. 2D, E and 2H, I). S8 specimens in contrast have A4 chaetae with an indistinct plateau, a slender blade-like shape and larger cusps that also cover the upper part of the stem (Fig. 2F, G).

S5 specimens have A4 chaetae characterised by having the median part of the ventral face (section between the oblique plateau and the vertical stem) covered with very large and 'aggressive' cusps and by an upper tip not oblong but sharp (Fig. 2J).

S7 specimens have A4 chaetae which resemble those from $\mathrm{S} 1$ in having large cusps and an asymmetric hull, but they are less numerous (Fig. 2K, L). In addition, the chaetae are rectangular in shape ventrally, whereas on S1 specimens they appear triangular when viewed from the same angle.

\section{Taxonomic remarks}

S1 specimens (Cape Verde Islands) clearly differ from the Pacific ones (i.e. S2, S8 and S9). The original description of Mesochaetopterus minuta by
Potts (1914) was based on specimens collected around Torres Strait, with the addition of specimens from the Atlantic, from sites over a distance of close to $180^{\circ}$ longitude. Although we did not examine specimens from this exact location, our observations on the morphology of the hard structures from uncinal plates and A4 chaetae demonstrate that a remarkable differentiation may occur over this geographic range.

Differences also occur over short geographic distances, as shown by the Solomon Islands populations (S2 and S9 versus S8) (see the map of the stations in Gibbs, 1971 p. 103). However, this is not an unexpected result. For instance, Spiochaetopterus costarum and S. solitarius, present in Banyuls Bay, diverge in body size, shape of A4 chaetae and, also, in reproductive periods which are 6 months apart (Bhaud, personal observation). In some cases, highly specific morphological structures can be identified, the most relevant occurring on Persian Gulf specimens, where the central chaeta of A4 had a morphology evoking the hull of a slender ship. 


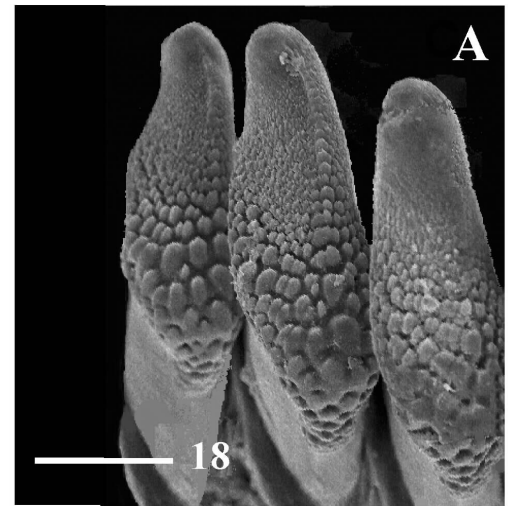

Cape Verde Islands(S1)

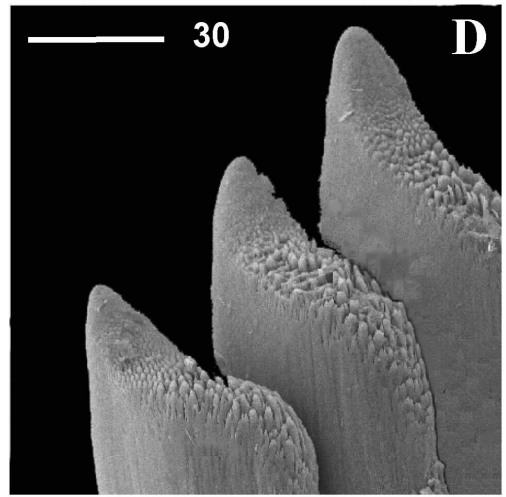

Solomon Islands (A) (S2)

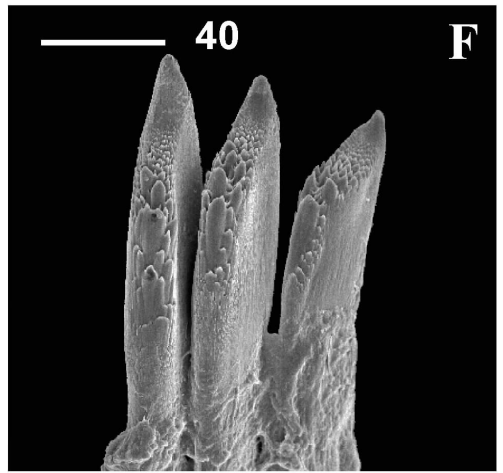

Solomon Islands (B) (S8)

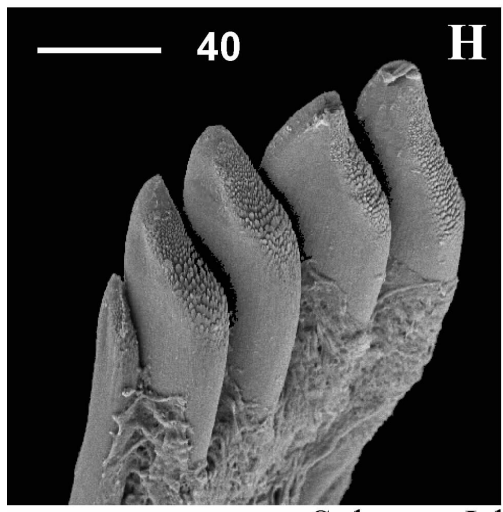

Solomon Islands (C) (S9)

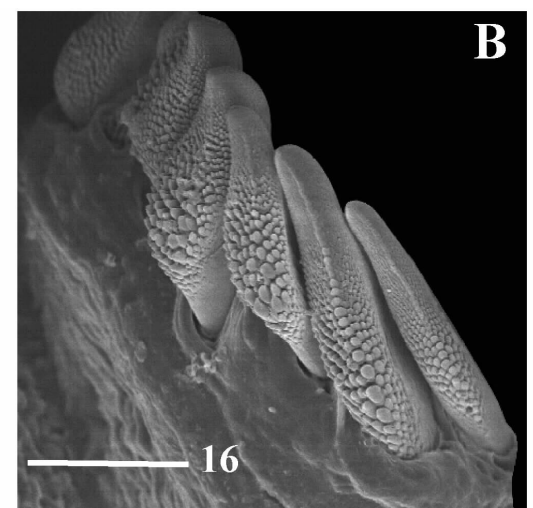

PersianGulf (S6)
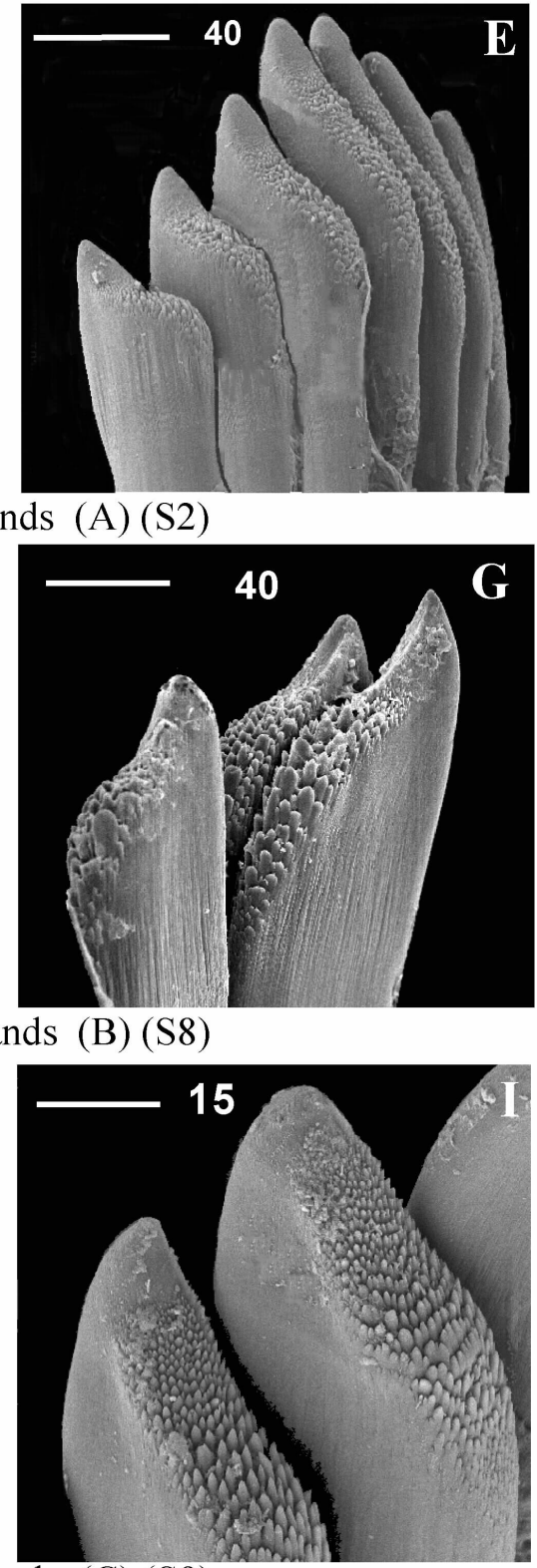

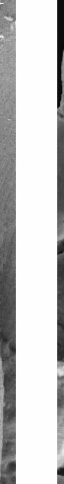

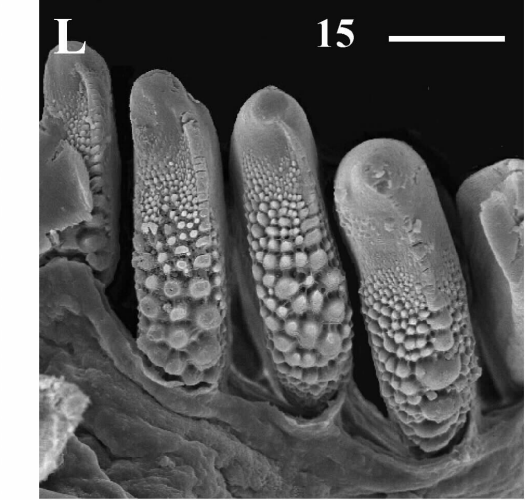

FIG. 2. - Comparison of A4 specialized chaetae of Mesochaetopterus. Geographical location as in Fig. 1. In brackets: code referring to the origin of the record. One photograph is displayed for each location, except for the Solomon Islands where two illustrations are provided for $\mathrm{A}, \mathrm{B}$ and $\mathrm{C}$ locations, and for the Galapagos Islands. 
TABLE 2. - Biogeographical distribution of two small-bodied species of Mesochaetopterus (i.e. M. sagittarius and M. minutus) in the Atlantic and Pacific basins. Both the original name and the proposal according to the morphology of chaetal hard structures are included. Bold rows correspond to the definition of the terra typica atlantica and terra typica pacifica for $M$. minuta.

\begin{tabular}{|c|c|c|c|c|}
\hline Authors & Year & Locations & Original name & Present proposal \\
\hline \multicolumn{5}{|l|}{ EUROPEAN WATERS } \\
\hline Claparède & 1870 & Mediterranean Sea & M. sagittarius & M. sagittarius \\
\hline Bhaud & 1969 & Mediterranean Sea. & M. minutus & M. sagittarius \\
\hline Bhaud & 1975 & Mediterranean Sea & M. minutus & M. sagittarius \\
\hline Potts & 1914 & Cape Verde Island & M. minuta & M. sagittarius \\
\hline Bhaud et al. & 2002 & Atlantic coasts & M. sagittarius & M. sagittarius \\
\hline \multicolumn{5}{|l|}{ PACIFIC WATERS } \\
\hline Potts & 1914 & Australia: Torres Straits & M. minuta & M. minutus \\
\hline Bailey-Brock & 1987 & Hawaii & M. sagittarius & M. minutus \\
\hline Gibbs & 1972 & Cook Islands & M. sagittarius & M. minutus \\
\hline Gibbs & 1978 & Great Barrier Reef & M. sagittarius & M. minutus \\
\hline Hutchings and Murray & 1984 & Australia: Hawkesbury River & M. minutus & M. minutus \\
\hline Imajima and Hartman & 1964 & Japan & M. minuta & M. minutus \\
\hline Ohwada & 1985 & Japan: Aburatsubo Bay & M. minuta & M. minutus \\
\hline Nishi and Arai & 1996 & Okinawa Island & M. sagittarius & M. minutus \\
\hline Kohn and Lloyd & 1973 & Easter Island & M. minutus & M. minutus \\
\hline
\end{tabular}

The question if it is now possible to define new species, in view of these differences, seems premature, since the body structures, e.g. number of segments in A-region, presence or absence of eye spots, organisation of B-region, disposition of neuropodia, have not been examined here. However, it is possible to cast some light on the current status of Mesochaetopterus minutus. The genus was first described as Ranzania sagittaria Claparède, 1870 then as Mesochaetopterus taylori Potts, 1914 and M. minuta Potts, 1914. As the genus Ranzania was preoccupied, it was referred to Ranzanides Chamberlin, 1919 (Hartman, 1959: 398). Then, it was considered that Mesochaetopterus Potts, 1914 included Ranzanides Chamberlin, 1919 (Day, 1967; Bhaud, 1969; Gibbs, 1972 and, probably, Gitay, 1969; Kudenov, 1975). Thus, according to Fauchald (1977), the genera Ranzania Claparède, 1870 and Ranzanides Chamberlin, 1919 are invalid and, at present, the genus Mesochaetopterus includes chaetopterids with three distinct body regions, one pair of long palps, unilobed median notopodia that are never fused, less than $5 \mathrm{~B}$ segments, and several stout chaetae on A4.

Some authors (Bhaud, 1969; Bailey-Brock, 1979; Nishi and Arai, 1996; Nishi, 1999) synonymised Mesochaetopterus sagittarius (Claparède, 1870) with M. minutus (Potts, 1914). Consequently, $M$. minutus was supposedly distributed in a circumtropical and intertropical belt which included the Atlantic, Indian and Pacific Oceans. It has also been collected in warm temperate provinces, with its northern boundary probably related to and limited by winter temperature. Its affinity for the tropics is corroborated by having a long reproductive period, which became shorter in temperate latitudes such as in the Mediterranean Sea. This scenario suggests $M$. minutus, like Spiochaetopterus typicus (see Bhaud, 1998) may represent a species complex currently imperfectly identified and containing several species, each with their own more restricted distributional area.

The morphological differences between the Atlantic (Cape Verde Islands and Portugal), Persian Gulf (Iranian Coasts) and Indian Ocean specimens (Bhaud, unpublished data) suggest the existence of different species at each locality. In the light of present observations, we propose that the AtlantoMediterranean species be referred to M. sagittarius, sensu Claparède (1870) while the Pacific species be referred to M. minutus, sensu Potts (1914), even though numerous authors quoted $M$. sagittarius for both the Pacific and the Mediterranean, and Bhaud (1969) quoted M. minutus for the Mediterranean (Table 2).

\section{DISCUSSION}

The differences in A4 chaetal shape may simply reflect changes linked to ontogenesis, rather than being species-specific features. For instance, rounded, blunt, relatively flat cusps may simply belong to old chaetae that have been in use for a long time. The observations of Pacific Mesochaetopterus larvae (i.e. necessarily bearing young chaetae) revealed 
cusps showing the adult morphology. Thus, morphology of each chaetal element, either resembling spines or paving blocks, seems to be defined from the earliest developmental phases. As for A4 specialized chaetae the observations of the uncinal plates on larvae and adult specimens from the European Atlantic coast (Bhaud et al., 2002) and from Nosy-Bé Island, Indian Ocean, (Bhaud, unpublished observations) support the premise that they keep a similar shape throughout their life cycle.

Uncinal plates may appear to have an additional source of variability, linked to the slide preparation method required for examination using light microscopy which can compress the plates. This may affect the plates even from the same segment and variations caused by compression may be visible in a slide preparation from the same specimen. For it to be valid as species-specific morphology, the source of variation, therefore, should be sought in differing plate dispositions. The best disposition is horizontal, but not all plates in a single preparation may lie in that position. Despite this possible methodological artefact a natural source of variability could well exist and should be taken into account in any taxonomical discussion. For instance, a valid discriminatory character seems to be the disposition of the posterior edges, which may be either more or less inclined or vertical.

Another source of uncertainty may be associated with intraspecific variability, which may be linked, for instance, to different ecological conditions. This point must be discussed in the context of phenotypic plasticity (Pigliucci, 2001). Many species show differences in body shape or physiological traits that are not criteria on which the erection of new species can be based (viz., Stearns, 1994; Harvell, 1998; Leonard, 1999; Pim, 2000; Trussell, 2000). The possibility that the geographic differences observed in hard structures of Mesochaetopterus may be caused by phenotypic plasticity cannot be totally disregarded. However, it must be pointed out that systematics researchers usually do not worry unduly about this possibility so that virtually all new species have been erected in the past without discussing this problem.

On the other hand, providing that the hard structure differences are species-related, it must be decided as to whether these differences are sufficiently species-specific to warrant us erecting new species without considering the description of soft structures. Currently, all the species of Mesochaetopterus fit the following description: small or large size, living gregariously in more or less dense masses of sandy tubes; body divided into 3 regions, colourless; buccal segment with long grooved palps but no tentacular cirri. A-region with 9-14 segments; chaetiger 4 with numerous $(>5)$ modified chaetae. B-region with 2-3 long segments with simple transversally flattened notopodia, each one carrying 2-3 chaetae; neuropodia with two uncinigerous tori with no variation in their disposition from segments 1 to 3 . $\underline{\mathrm{C}-}$ region with numerous segments, each with short conical or spherical notopodia with a single chaeta. Such a description suggests that many descriptive characters have not been fully evaluated in spite of useful comparative descriptions of body structures (Petersen and Fanta, 1969; Nishi, 1999). For instance, the significance of the variations in seg-

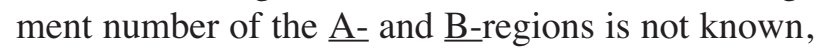
the existence of sexually mature specimens among small species has not been corroborated, (i.e. are these 'small species' perhaps still growing and how long does it take for them to reach their largest size?). These questions cannot be solved unless certain elementary biological experiments are carried out.

Finally, the relationships between different morphological characters may affect the exact description of individuals. Nishi (1999), for example, mentioned that the position of the peristomium relative to the prostomium could explain the variability in species descriptions of the presence or absence of eyes: in specimens where the peristomium partly surrounds the prostomium the eyes are visible, whilst they cannot be seen when the peristomium completely surrounds the prostomium.

Taking into account all the above concepts, it seems likely that hard structures supply objective criteria for species differentiation, within the genus Mesochaetopterus and perhaps also within the Chaetopteridae as a whole.

\section{CONCLUSIONS}

This is the first time that uncinal plates and specialised A4 chaetae of Mesochaetopterus have been observed on a large number of specimens from several geographic regions using SEM as well as light microscopy. This has led to the identification of morphological variations in hard structures which have shown finer geographical divergences than the 
criteria linked to soft body structures alone. It is likely that these differences are species-specific.

Potts (1914) erected $M$. minuta both from Atlantic (Cape Verde Islands) and Pacific (Australia, Torres Strait) locations almost $180^{\circ}$ apart longitudinally. However, our own observations lead us to recognise the existence of differences over a much smaller geographic range. Atlantic and Mediterranean specimens seems to differ from the Indian and Pacific Ocean ones, whilst the Persian Gulf specimens apparently belong to a species differing from Nosy-Bé Island ones (Bhaud, personal observations). Consequently, our results strongly support the reintroduction of $M$. sagittarius (Claparède, 1870) for the Atlanto-Mediterranean specimens. The Pacific situation is more complex, since two morphologies occur in a relatively small area (Solomon Islands). Currently, we cannot assess which one of them corresponds to the terra typica pacifica (Torres Strait) population.

A general result for the genus Mesochaetopterus, and probably for the whole family now that partial data for Spiochaetopterus (Nishi, 1999) has been gathered, is that it is becoming increasingly difficult to support the existence of cosmopolitan species. The family is now credited with significantly higher biodiversity than before with each species covering a smaller area than previously thought. The putative cosmopolitanism of chaetopterid species, before the recent description of new species, was the result of both inadequate morphological examination and the use of questionable ecological arguments linked to larval dispersal. It has not been proven that longlived planktonic larvae are effectively transported over long distances thus promoting geographical homogeneity giving rise to truly cosmopolitan species.

\section{ACKNOWLEDGEMENTS}

The authors express their gratitude to Dr Gordon Paterson, Department of Zoology, The Natural History Museum, London, U.K. for having put at our disposal a particularly interesting collection of samples. We are grateful to Dr Gourand, University of Perpignan (France) who facilitated the use of the Hitachi S4500 SEM-FEG and helped us to obtain fine photographs. We wish to thank M. Codina and P. Tirado for help with the preliminary sorting of macrofauna from the Persian Gulf. The study has been partly financed by a research contract between the CEAB (CSIC) and the French company CREOCEAN and has been partly sponsored by TOTAL. This paper is also a contribution to the research project INTAS-OPEN-97-0916.

\section{REFERENCES}

Bailey-Brock, J.H. - 1979. Sediment trapping by chaetopterid polychaetes on a Hawaiian fringing reef. J. Mar. Res., 37: 643-656.

Bailey-Brock, J.H. - 1987. Annelida. In: D.M. Devaney and L.G. Eldredge (eds.), Reef and shore fauna of Hawaii, pp. 213-454. Bernice P. Bishop Mus. Spec. Publ. 64, Honolulu.

Barnes, R.D. - 1965. Tube-building and feeding in chaetopterid polychaetes. Biol. Bull., 129: 217-233.

Bhaud, M. - 1969. Remarques systématiques et biogéographiques sur le genre Mesochaetopterus Potts, 1914. Vie Milieu, 20: 325-332.

Bhaud, M. - 1975. Présence de Mesochaetopterus minutus (Annélide Polychète), Chaetopteridae) dans la region de Banyuls-sur-Mer. Vie Milieu, 25: 341-344.

Bhaud, M. - 1998. The species of the genus Spiochaetopterus (Polychaeta, Chaetopteridae) in the Atlantic-Mediterranean biogeographic area. Sarsia, 83: 243-263.

Bhaud, M. - 2003. Identification of adults and larvae in Spiochaetopterus (Polychaeta, Chaetopteridae): consequences for larval transport and recruitment. Hydrobiologia, 496: 279-287.

Bhaud, M., A.A. Ravara, G. Marcano and M.H. Moreira. - 2002. Mesochaetopterus sagittarius: an example of a biogeography discrepancy between larval and adult boundaries: implication for recruitment studies. J. Mar. Biol. Assoc. U.K., 82: 565-572.

Chamberlin, R.V. - 1919. The Annelida Polychaeta. Mem. Mus. Comp. Zool. Harward Coll., 48: 1-514.

Claparède, É. - 1870. Les Annélides Chétopodes du Golfe de Naples. Mém. Soc. Phys. Hist. nat. Genève, 20: 1-225.

Day, J.H. - 1967. A monograph on the Polychaetes of Southern Africa. Part 1. Errantia. T. British Mus. Nat. Hist., 656: 1-656.

Fauchald, K. - 1977. Polychaete worms, definitions and keys to the orders, families and genera. Nat. Hist. Mus. Los Angeles County Sci.Ser., 28: 1-190.

Fauvel, P. - 1953. Annelida Polychaeta. In: R.B. Seymour-Sewell (ed.), The Fauna of India including Pakistan, Ceylon, Burma and Malaya, pp. 1-507. Allahabad.

Gibbs, P.E. - 1971. The polychaete fauna of the Solomon Islands. Bull. Br. Mus. Nat. Hist, 21: 101-211.

Gibbs, P.E. - 1972. Polychaete annelids from the Cook Islands. $J$. Zool.(Lond.), 168: 199-220.

Gibbs, P.E. - 1978. Macrofauna of the intertidal sand flats on low wooded islands, northern Great Barrier reef. Phil. Trans. R. Soc. London, 284: 81-97.

Gitay, A. - 1969. A contribution to the revision of Spiochaetopterus (Chaetopteridae, Polychaeta). Sarsia, 37: 9-20.

Hartman, O. - 1941. Polychaetous annelids. Pectinariidae, with a review of all species from the Western Hemisphere. Allan Hancock Pacific Exp., 7: 325-345.

Hartman, O. - 1959. Catalogue of the Polychaetous Annelids of the world, parts 1-2. Allan Hancock Found. Publ. Occ. Pap., 23: $1-628$.

Harvell, C.D. - 1998. Genetic variation and polymorphism in the inducible spines of a marine bryozoan. Evolution, 73: 1567-1576.

Holthe, T. - 1986. Evolution, systematics and description of the Polychaeta Terebellomorpha, with a catalogue of the taxa and a bibliography. Gunneria, 55: 1-236.

Hutchings, P.A. and A. Murray. - 1984. Taxonomy of Polychaetes from the Hawkesbury River and the Southern Estuaries of New South Wales, Australia. Rec. Aust. Mus., 36: 1-119.

Imajima, M. and O. Hartman. - 1964. The Polychaetous Annelids from Japan. Pt. I. Allan Hancock Found. Spec. Publ., 26: 1-237.

Knight-Jones, P. - 1994. Two new species of Branchiomma (Sabellidae) with redescriptions of closely related species and comments on Pseudobranchiomma and Sabellastarte. Mém. Mus. Natn. Hist. Nat. Paris, 162: 191-198. 
Kohn, A.J. and M.C. Lloyd. - 1973. Marine polychaete annelids of Easter Island. Int. Revue ges. Hydrobiol., 58: 691-712.

Kudenov, J.D. - 1975. Sedentary polychaetes from the Gulf of California, Mexico. J. Nat. Hist., 9: 205-231.

Lana, P.C. and C.S. Bremec. - 1994. Sabellariidae (Annelida, Polychaeta) from South America. Mém. Mus. Natn. Hist. Nat. Paris, 162: 209-222.

Leonard, G.H. - 1999. Crab predation, waterborne cues, and inducible defences in the blue mussel Mytilus edulis. Ecology, 80: $1-14$.

Long, C. - 1973. Pectinariidae (Polychaeta) from Caribbean and associated waters. Bull.Mar. Sci., 23: 857-874.

Mohammad, M.B.M. - 1980. Polychaete annelids from Kuwaitian islands, Arabian Gulf, with descriptions of four new species. Zool. J. Linn. Soc. London, 69: 31-42.

Nishi, E. - 1999. Redescription of Mesochaetopterus selangolus (Polychaeta: Chaetopteridae), based on type specimens and recently collected material from Morib Beach, Malaysia. Pac. Sci., 53: 24-36.

Nishi, E. and Y. Arai. - 1996. Chaetopterid polychaetes from Okinawa Island, with notes on the feeding behaviour of Spiochaetopterus costarum costarum. Publs. Seto Mar. Biol. Lab., 37: 51-61.

Nishi, E. and M. Bhaud. - 2000. Two new species of Spiochaetopterus (Polychaeta: Chaetopteridae) from Okinawa, Japan, with notes on Pacific Spiochaetopterus. Pac. Sci., 54: 15-26.

Nishi, E., T. Miura and M. Bhaud. - 1999. A new species of Spiochaetopterus (Chaetopteridae: Polychaeta) from a coldseep site off Hatsushima in Sagami Bay, Central Japan. Proc. Biol. Soc. Wash., 112: 210-215.

Ohwada, T. - 1985. Prostomium morphology as a criterion for the identification of nephtyid polychaetes (Annelida: Phyllodocida), with reference to the taxonomic status of
Aglaophamus neotenus. Publs. Seto Mar. Biol. Lab., 30: 55-60. Petersen, J.A. and E.S. Fanta. - 1969. On two new species of Mesochaetopterus (Polychaeta) from the Brazilian coast. Beitr. Neotropisch. Fauna, 6: 120-136.

Pigliucci, M. - 2001. Phenotypic plasticity: Beyond nature and nurture. Ed. The Johns Hopkins University Press, Baltimore and London.

Pim, E. - 2000. Phenotypic plasticity of burrowing depth in the bivalve Macoma balthica: experimental evidence and general implications London. In: Harper, Taylor and Crame (eds.), The Evolutionary biology of the Bivalvia, pp. 451-458. Geological Society, London.

Potts, F.A. - 1914. Polychaetes from the NE Pacific: Chaetopteridae. With an account of the phenomenon of asexual reproduction in Phyllochaetopterus and the description of two new species of Chaetopteridae from the Atlantic. Proc. Zool. Soc. Lond., 67: 955-994.

Stearns, S.C. - 1994. The evolution of life histories. Third Ed. Oxford University Press, New York.

Trussell, G.C. - 2000. Predator induced plasticity and morphological trade-offs in latitudinally separated populations of Littorina obtusata. Evol. Ecol. Res., 83: 803-822.

Vogt, K.D. and J.D. Kudenov. - 1994. Morphometric variation in bifurcate notosetae of two Euphrosine species (Polychaete, Euphrosinidae). Mém. Mus. Natn. Hist. Nat. Paris, 162: 291-298.

Watson-Russell, C. - 1998. Description of Arichlidon new genus and two new species from Australia; Bhawania reyssi redescribed and assigned to Arichlidon (Chrysopetalidae: Polychaeta). The Beagle, Rec. Mus. Art. Galleries North. Territory, 14: 159-176.

Received September 16, 2004. Accepted May 11, 2005. 